УДК 159.922 .8

\title{
ЦЕННОСТНЫЕ ОРИЕНТАЦИИ СОВРЕМЕННОГО СТУДЕНЧЕСТВА
}

Аннотаиия. Целью представценного в статье исследования было изучение динамики ценностных ориентаций студентов педагогического вуза, предметом ценностно-мотивационная сфера испытуемых. Методология работы основывалась на принципе системного детерминизма и заключалась в теоретическом и практическом обосновании проблемы ценностных ориентаций как основного компонента познавательного интереса студенческой молодежи.

Полученные результаты, показавшие повышение значимости сферы профессиональной деятельности от курса к курсу, могут быть учтены в процессе формирования ценностно-мотивационной сферы студентов. Анализ рассматриваемой проблематики позволяет констатировать, что формирование ценностных ориентаций будет более успешным в случае создания в образовательном пространстве специальных социально-психологических условий.

Ключевые слова: ценностные ориентации, ценности, студенчество.

Abstract. The study is aimed at investigating the dynamics of students' value orientation at the pedagogic higher school. The subject of the research incorporates the value-motivation sphere as being the component of students' cognitive interest. The research methodology is based on the system determinism principle and combines the theoretical and practical substantiation of the value orientation problem as the main component of students' cognitive interest.

The research results referred to the professional activity values, growing year after year during the undergraduate course, can be taken into account in developing the value-motivation sphere of the studentship. The research shows that the proper psychological conditions created in the educational environment make the development of the value orientation system more successful.

Index terms: system of values, values, studentship.

Студенческий возраст - 17-23 года - наиболее плодотворный дмя формирования знаний, научного и профессионального роста, совершенствования всесторонней культуры период. Он характеризуется развитием вербального интемлекта и рефлексии, динамичностью возбуждения, повышением уровня наблюдательности. В переходные, кризисные периоды

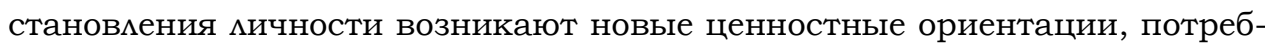
ности и интересы, а на их основе видоизменяются мичностные качества, характерные дия предшествующего периода. Таким образом, ценностные 


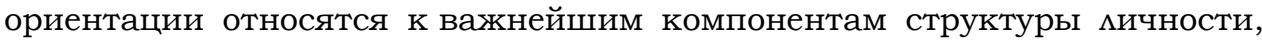
по степени развитости которых можно судить об уровне ее сформированности. Они связаны со становцением самосознания, осознания положения собственного “Я" в системе общественных отношений, формирующих мотивационно-потребностную сферу.

Согмасно психомого-педагогической митературе, ценность - это принятое в философии, этике, эстетике, социологии, психоцогии понятие, с помощью которого характеризуется социально-историческое значение определенных явлений действительности для общества и человека. Функции ценностей заключаются в осуществцении выбора: в соответствии с ними субъект принимает решение о том, что, в какой очередности и каким способом реализовать из множества потребностей и возможностей в определенных условиях. Содержание ценностей обусловлено культурными достижениями общества. Мир ценностей - это, прежде всего, мир культуры в широком смысле слова, сфера духовной деятельности человека, его нравственного сознания, его привязанностей - тех оценок, в кото-

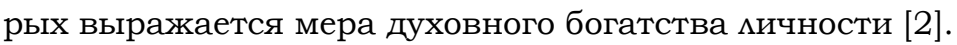

Ценностная сфера связана с усложнением стимулов поведения человека и причин социального действия. На первый план выступает не то, что, безусловно, необходимо, без чего нельзя существовать (эта задача решается на уровне потребностей), не то, что выгодно с точки зрения материальных условий бытия (это уровень действия интересов), а то, что соответствует представлению о назначении человека и его достоинстве. Речь идет о тех аспектах мотивации поведения, в которых проявляется самоутверждение и свобода мичности. Осознание ценности предполагает наличие у человека определенного способа ориентировки в каком-либо классе, виде, группе ценностей, являющейся внутренним психологическим механизмом, формирующим определенные предпочтения мичности, по характеру и направленности которых можно понять особенности ее ценностных ориентаций.

Ценностные ориентации - сравнительно устойчивое, избирательное отношение человека к совокупности материальных и духовных благ и идеалов, которые рассматриваются как предметы, цели или средства для удовцетворения потребностей жизнедеятельности мичности. В этой сфрере как бы аккумулируется весь жизненный опыт, накопленный в индивидуальном развитии чемовека [1]. Он характеризует жизненные при-

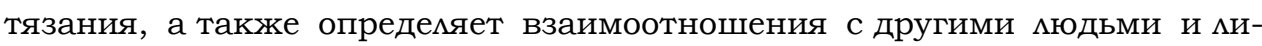
нию поведения индивида. 
Приведенное опредемение, на наш взгляд, наиболее полно отражает содержание и динамичный характер ценностных ориентаций человека, их функции и значение в его жизни и личностном развитии. Изучение влияния рассматриваемого феномена на размичные сферы деятельности подтверждает положение о том, что общие и специфические условия деятельности, преломляясь в сознании, по-разному проявляются в реальном поведении. Причина существенных различий в поведении мюдей кроется в субъективном восприятии данных условий, а также в разнице ценностных ориентаций и структуры жизненных ценностей [3].

Рост интереса исследователей к измерению ценностей и ценностных ориентаций наметился с начала 60-х гг. и был связан с консультированием по вопросам образования и выбора профессии, прогнозированием социального поведения индивидов $[1,5]$. Среди известных тестов дмя диагностики различных аспектов направленности мичности могут быть названы методика словацкого психолога Т. Тарочковой "Жизненные цели", тест американских авторов Д. Сьюпера и Д. Невиц "Шкала ценностей", методика М. Рокича "Изучение ценностей человека", опросник Олпорта - Верона - Аиндсея и др. [6].

В отечественной практике профконсультирования долгое время был распространен подход, основывающийся на том, что профессиональная деятельность является основным содержанием жизни человека. Однако практика показала, что дмя одного чемовека профессиональная жизнь это возможность удовлетворения потребности в общении, дмя другого средство зарабатывания денег, дмя третьего она не имеет особенной значимости, поскольку он отводит первое место сфере семейной жизни и т. д. Таким образом, сопоставмяя преобладающие ценностные ориентации с доминирующими жизненными сферами, можно определить и доминирующую направленность мичности.

Проведенное нами исследование бымо направлено на решение двух задач:

1) определить специфические особенности ценностных ориентаций студентов разных факультетов;

2) выявить динамику ценностных ориентаций студентов каждого факультета на протяжении обучения в педагогическом вузе.

В исследовании приняли участие студенты первого и выпускного курсов трех факультетов: истории и права, филологического факультета и факультета коррекционной педагогики и психологии. Выбор факультетов объяснялся тем, что содержание преподаваемых на них дисциплин универсаль- 
но и вкцючает психологические аспекты знания. Кроме того, поскольку представители выбранных факультетов - люди творческие, их студенческая жизнь чрезвычайно интересна, насыщенна и динамична. Срезы проводимись в 2008/09 уч. г. на базе Шадринского государственного педагогического института. В качестве диагностического инструмента использовался опросник терминальных ценностей (ОТеЦ) [4], который позволяет выявить иерархию ценностных ориентаций человека и преобладающие сферы его жизнедеятельности, а также степень значимости для индивида той или иной жизненной сферы, в рамках которой он пытается себя реализовать. Результаты обрабатывались на IBM PC-AТ. Нас интересовали только высокие оценки по всем изучаемым шкалам (7-10), так как они дают представление о доминировании той или иной ценности. Поэтому средние арифметические значения для сравнения между собой отдельных групп студентов не использовались. Мы сочии более целесообразным учитывать процентное отношение высоких оценок по каждой шкале к общему числу студентов группы.

Результаты исследования представцены в табл. 1.

Таблица 1

Количественное распределение студентов по методике ОТеЦ

\begin{tabular}{|c|c|c|c|}
\hline \multirow{3}{*}{ Шкалы методики } & \multicolumn{3}{|c|}{ Факультет } \\
\hline & $\begin{array}{c}\text { коррекцион- } \\
\text { ной педаго- } \\
\text { гики и пси- } \\
\text { хологии }\end{array}$ & $\begin{array}{l}\text { истории } \\
\text { и права }\end{array}$ & $\begin{array}{c}\text { фимологи- } \\
\text { ческий }\end{array}$ \\
\hline & \multicolumn{3}{|c|}{ 1-й / 5-й курс } \\
\hline \multicolumn{4}{|c|}{ Ценностные ориентаиии } \\
\hline 1. Престиж & $40 / 36$ & $45 / 20$ & $35 / 44$ \\
\hline 2. Материальное положение & $83 / 82$ & $65 / 73$ & $62 / 80$ \\
\hline 3. Креативность & $52 / 33$ & $32 / 20$ & $23 / 34$ \\
\hline 4. Активные социальные контакты & $52 / 33$ & $57 / 40$ & $44 / 32$ \\
\hline 5. Развитие себя & $74 / 48$ & $47 / 40$ & $58 / 62$ \\
\hline 6. Достижения & $98 / 73$ & $80 / 60$ & $70 / 62$ \\
\hline 7. Духовное удовметворение & $55 / 18$ & $37 / 20$ & $13 / 36$ \\
\hline $\begin{array}{l}\text { 8. Сохранение собственной ин- } \\
\text { дивидуальности }\end{array}$ & $79 / 79$ & $70 / 60$ & $60 / 74$ \\
\hline \multicolumn{4}{|c|}{ Жизненные сфреры } \\
\hline 1. Профессиональная деятемьность & $69 / 64$ & $40 / 40$ & $29 / 42$ \\
\hline 2. Обучение и образование & $73 / 54$ & $72 / 60$ & $64 / 60$ \\
\hline 3. Семья & $67 / 54$ & $45 / 40$ & $43 / 50$ \\
\hline 4. Общественная жизнь & $76 / 21$ & $50 / 40$ & $58 / 36$ \\
\hline 5. Увцечения & $75-64$ & $67 / 46$ & $67 / 64$ \\
\hline
\end{tabular}


Проанализировав полученные результаты, мы выявили общие тенденции в области ценностных ориентаций всех испытуемых.

1. Значительная часть студентов получили высокий балм по показателю "высокое материальное положение" (от 62 до 83\%). Это означает, что материальное благосостояние служит основанием для развития чувства собственной значимости и положительного отношения к себе. Заинтересованность в материальном благополучии объясняется возросшими потребностями молодых Аюдей студенческого возраста и их низкой социальной защищенностью.

2. Испытуемым свойственна высокая потребность в достижениях (от 60 до 98\%), т. е. стремление к получению ощутимых и конкретных результатов в Аюбом виде деятельности. Эта потребность объясняется самим характером учебной деятельности студентов.

3. Большинство студентов (от 60 до 79\%) считают важным сохранение собственной индивидуальности, что свидетельствует о стремлении к независимости от других, проявлению неповторимости, Аичностного своеобразия, свободному выражению своих взглядов и убеждений.

4. Вопреки нашим ожиданиям, немногие студенты ставят удовлетворение своих духовных потребностей выше материальных (от 13 до 55\%).

5. Наиболее значимыми дмя всех респондентов сферами жизнедеятельности являются сферы обучения и увлечений, причем значимость второй превалирует у обучающихся на факультете коррекционной педагогики и психологии и филологическом факультете.

6. Большинство студентов пока не осознают важности профессиональной сферы. Они редко задумываются о завтрашнем дне, профессиональная деятельность является дия них чем-то непривлекательным и неизвестным. Их гораздо больше устраивает беззаботная и более привычная студенческая жизнь, в которой учеба соперничает с их мюбимыми занятиями.

Особенных различий в ценностных ориентациях студентов отдельных факультетов мы не обнаружили, однако выявили различия в динамике ценностных ориентаций от 1-го курса к 5-му.

Дия анализа названной динамики мы проранжировали все ценности и жизненные сферы по их значимости дмя студентов каждого курса. Ранговые места (от 1-го до 8-го дмя ценностных ориентаций и от 1-го до 5-го дия жизненных сфер, где 1 - наиболее значимая ценность) представмены в табл. 2. 
Таблица 2

Значимость для испытуемых ценностных ориентаций и жизненных сфер

\begin{tabular}{|c|c|c|c|}
\hline \multirow{3}{*}{ Показатель } & \multicolumn{3}{|c|}{ Факультет } \\
\hline & $\begin{array}{c}\text { коррекцион- } \\
\text { ной педагоги- } \\
\text { ки и психоло- } \\
\text { гии }\end{array}$ & $\begin{array}{l}\text { истории } \\
\text { и права }\end{array}$ & $\begin{array}{l}\text { фимологи- } \\
\text { ческий }\end{array}$ \\
\hline & \multicolumn{3}{|c|}{ 1-й / 5-й курс } \\
\hline \multicolumn{4}{|c|}{ Ценностные ориентаиии } \\
\hline 1. Престиж & $7-5$ & $6-4$ & $6 / 4$ \\
\hline 2. Материальное поможение & $2 / 1$ & $3 / 1$ & $2 / 1$ \\
\hline 3. Креативность & $6 / 6$ & $8 / 4$ & $5 / 7$ \\
\hline 4. Активные социальные контакты & $6 / 6$ & $4 / 3$ & $4 / 3$ \\
\hline 5. Развитие себя & $4 / 4$ & $5 / 3$ & $1 / 3$ \\
\hline 6. Достижения & $1 / 3$ & $1 / 2$ & $8 / 5$ \\
\hline 7. Духовное удов етворение & $5 / 7$ & $7 / 4$ & $3 / 2$ \\
\hline $\begin{array}{l}\text { 8. Сохранение собственной ин- } \\
\text { дивидуальности }\end{array}$ & $3 / 2$ & $2 / 2$ & $5 / 4$ \\
\hline \multicolumn{4}{|c|}{ Жизненные сорерь } \\
\hline 1. Сфера профессиональной жизни & $4 / 1$ & $5 / 3$ & $5 / 4$ \\
\hline 2. Сфрера обучения и образования & $3 / 2$ & $1 / 1$ & $2 / 2$ \\
\hline 3. Сфера семейной жизни & $5 / 2$ & $4 / 3$ & $4 / 3$ \\
\hline 4. Сфера общественной жизни & $1 / 3$ & $3 / 3$ & $3 / 5$ \\
\hline 5. Сфрера увмечений & $2 / 1$ & $2 / 2$ & $1 / 1$ \\
\hline
\end{tabular}

Проанализировав перечисленные результаты, мы пришли к следующим выводам относительно динамики ценностных ориентаций студентов педвуза от первого курса к выпускному.

1. Стремление к материальной обеспеченности увсех студентов имеет тенденцию к повышению и к старшим курсам переходит со 23-го места на 1-е. Первокурсники, вчерашние школьники, гораздо терпимее относятся к материальной зависимости от родителей. Студенты же старших курсов имеют более высокие потребности, стремятся быть независимыми от родителей, создать собственную семью.

2. Наиболее значимая дмя всех первокурсников ценность- потребность в достижениях (у всех на 1-м месте) - имеет тенденцию к снижению (на 2-3-е место), оставаясь, однако, одной из наиболее значимых в структуре ценностных ориентаций студентов.

3. Третьей по значимости дмя первокурсников явцяется потребность в сохранении собственной индивидуальности, которая к 5-му курсу занимает уже второе место в структуре ценностей студентов, т. е. усицивается в процессе обучения и взросления. 
4. Аналогичным образом развивается стремление к саморазвитию. У большинства студентов потребность к самоактуализации к 5-му курсу возрастает и выходит на 4-е место (3-е на факультете коррекционной педагогики и психологии).

5. На протяжении обучения в институте увеличивается стремление студентов к завоеванию авторитета, признания, поддержанию собственного престижа. Эта потребность выходит к 5-му курсу на 4-е место и объясняется процессом изменения социального статуса выпускников по сравнению с первокурсниками (кроме того, многие старшекурсники начинают работать, создают собственную семью).

6. Стремление к активным социальным контактам, креативность и духовное удовиетворение не занимают значительного места в ценностной сфере большинства студентов.

7. Важно отметить повышение значимости в ходе обучения сферы профессиональной деятельности. Однако, несмотря на эту тенденцию, даже для пятикурсников она остается едва $九 и$ не на последнем месте. ИскАючение составляет мишь факультет коррекционной педагогики и психомогии, где к выпускному курсу профессиональной жизни отводится 1-е место.

8. Сфера обучения является наиболее значимой дмя студентов факультета истории и права (1-е место как на первом, так и на 5-м курсе). На фимологическом факультете эта сфера занимает 2-е место, уступая сфере увлечений. У студентов факультета коррекционной педагогики и психологии к выпускному курсу происходит снижение значимости обучения.

9. Интерес к семейной жизни, не являясь преобладающим, возрастает от первого курса к старшим, что, на наш взгяяд, совершенно естественно и связано со стремлением к образованию собственной семьи.

10. Значимость общественной жизни, в свою очередь, имеет тенденцию к снижению. Это объясняется тем, что на первых курсах студенты стремятся найти свое место в коммективе сверстников, занять опредеменную позицию в группе, расширить круг знакомств. К старшим курсам эта потребность у большинства уже удовлетворена: сложился определенный круг общения, определилось положение в референтной группе. Поэтому интерес к общественным мероприятиям у пятикурсников значительно ниже, чем в начале обучения.

11. Сфера увлечений занимает одно из важнейших мест в жизни студентов (1-2-е) на протяжении всего периода обучения. 
Результаты, полученные в ходе нашего исследования на ограниченной выборке, тем не менее обнаруживают некоторые общие закономерности динамики ценностных ориентаций современного студенчества.

ДАя совершенствования вузовского образовательного процесса требуется создание на основе учета мотивационно-потребностных характеристик студентов специальных условий, способных обеспечить развитие ценностно-мотивационной сферы студенческой молодежи. К таким условиям могут быть отнесены, во-первых, методы обучения, актуализирующие терминальные и инструментальные ценности студентов, а именно активные и интерактивные методы; во-вторых, приемы и методы, направленные на создание в ходе учебного процесса стенических интелмектуальных и праксических чувств и переживаний.

\section{Аитература}

1. Бойков В. Э. Ценностные ориентации россиян как фактор интеграции и дезинтеграции общества // Социология вмасти. 2009. № 7 . C. $29-41$.

2. Аисовский В. Т. Духовный мир и ценностные ориентации молодежи России: учеб. пособие дия студентов вузов / С.-Петербург. гуманитар. ун-т профсоюзов. СПб., 2000. 508 с.

3. Пцатонов А. Идеалы и ценности подрастающего поколения // Психол. газ. 2002. № 5. С. 25-26.

4. Сенин И. Г. Опросник терминальных ценностей. Ярославль, 1991.

5. Стойлик А. Ю. Ценностные ориентации: социально-психологический и гендерный аспекты // Журн. прикладной психологии. 2003. № 6. С. 60-69.

6. Фомичева Т. В. Образовательные ценности молодежи / Моск. гос. соц. ун-т. М.: Изд-во МГСУ, 2003. 201 с. 